Article

\title{
Degradative Ability of Mushrooms Cultivated on Corn Silage Digestate
}

\author{
Stefano Fornito ${ }^{1}$, Federico Puliga ${ }^{1, *} \mathbb{C}$, Pamela Leonardi ${ }^{1}$, Michele Di Foggia ${ }^{2}(\mathbb{D}$, \\ Alessandra Zambonelli ${ }^{1}$ (D) and Ornella Francioso ${ }^{1}$ (D) \\ 1 Department of Agricultural and Food Sciences, University of Bologna, Viale G. Fanin 40, \\ 40127 Bologna, Italy; stefano.fornito93@gmail.com (S.F.); pamela.leonardi@unibo.it (P.L.); \\ alessandr.zambonelli@unibo.it (A.Z.); ornella.francioso@unibo.it (O.F.) \\ 2 Department of Biomedical and Neuromotor Sciences, University of Bologna, Via Belmeloro 8/2, \\ 40126 Bologna, Italy; michele.difoggia2@unibo.it \\ * Correspondence: federico.puliga2@unibo.it; Tel.: +39-051-2096564
}

Academic Editor: George Zervakis

Received: 15 May 2020; Accepted: 30 June 2020; Published: 1 July 2020

\begin{abstract}
The current management practice of digestate from biogas plants involves its use for land application as a fertilizer. Nevertheless, the inadequate handling of digestate may cause environmental risks due to losses of ammonia, methane and nitrous oxide. Therefore, the key goals of digestate management are to maximize its value by developing new digestate products, reducing its dependency on soil application and the consequent air pollution. The high nitrogen and lignin content in solid digestate make it a suitable substrate for edible and medicinal mushroom cultivation. To this aim, the mycelial growth rate and degradation capacity of the lignocellulosic component from corn silage digestate, undigested wheat straw and their mixture were investigated on Cyclocybe aegerita, Coprinus comatus, Morchella importuna, Pleurotus cornucopiae and Pleurotus ostreatus. The structural modification of the substrates was performed by using attenuated total reflectance-Fourier transform infrared (ATR-FTIR) spectroscopy. Preliminary in vitro results demonstrated the ability of P. ostreatus, $P$. cornucopiae and M. importuna to grow and decay hemicellulose and lignin of digestate. Cultivation trials were carried out on C. aegerita, P. cornucopiae and P. ostreatus. Pleurotus ostreatus showed the highest biological efficiency and fruiting body production in the presence of the digestate; moreover, $P$. ostreatus and P. cornucopiae were able to degrade the lignin. These results provide attractive perspectives both for more sustainable digestate management and for the improvement of mushroom cultivation efficiency.
\end{abstract}

Keywords: corn digestate; white-rot fungi; lignin degradation; ATR-FTIR; mushroom cultivation

\section{Introduction}

Managing organic waste streams is a major challenge for the agricultural industry. Anaerobic digestion (AD) treatment process is considered the most suitable bioenergy technology to treat wastes for biogas production from agriculture, industry and household food wastes [1]. Public policies of several EU Member States have promoted the use of AD to treat organic wastes and to generate renewable energy. According to the estimates, about one-third of the EU's 2020 target for renewable energy in transport could be met by using biogas produced from biowaste, while around $2 \%$ of the EU's overall renewable energy target could be met if all biowaste was turned into energy [2].

Digestate is a heterogeneous material produced in large amounts during the AD process [3]. The physicochemical characteristics of digestate depend on the nature and composition of feedstocks, as well as on the operational parameters of the process. Agricultural wastes typically have a high content of lignocellulose. In this rigid structure, lignin coats cellulose and hemicellulose while blocking 
their degradation by anaerobic bacteria [4,5]. Pretreatment methodologies utilizing energy-intensive processes (high pressures and temperatures) and harsh chemical compounds $\left(\mathrm{NaOH}\right.$ and $\left.\mathrm{H}_{2} \mathrm{SO}_{4}\right)$ are currently used, in order to better perform their utilization in the AD process $[6,7]$.

One of the main questions about the reuse of digestate is how to prevent nutrient imbalances in the receiving environment. In agriculture, digestate is considered a useful nutrient source, but its use is influenced by the disposal limits for N and P [8]. Moreover, the digestate used as a fertilizer is still a source of greenhouse gases (GHG). These gases can be produced and emitted during digestate storage and during its spreading upon the field, although their impact is relatively lower than an untreated biomass [9]. However, the ammonia release and nitrate leaching are still a critical point with respect to $\mathrm{N}_{2} \mathrm{O}$ and $\mathrm{CH}_{4}$ emissions from digestate [10].

Therefore, new strategies and alternative uses of digestate are necessary in view of the growth of biogas plants [11].

Lignocellulolytic mushrooms are an attractive resource that allows the biotransformation of lignocellulosic wastes into a value-added bioproduct [12]. White-rot mushrooms such as Cyclocybe aegerita (V. Brig.) Vizzini, Ganoderma lucidum (Curtis) P. Karst., Ganoderma resinaceum Boud., Lentinula edodes (Berk.) Pegler, Pleurotus cornucopiae (Paulet) Rolland, Pleurotus ostreatus (Jacq.) P. Kumm. and Schizophyllum commune Fr. are the most effective mushrooms for delignification due to the production of a large variety of ligninolytic extracellular enzymes such as laccase, lignin manganese and versatile peroxidases, galactose oxidase, glyoxal and alcohol oxidase, benzoquinone reductases and lytic polysaccharide monooxygenases [13-15]. On the other hand, brown root mushrooms such as Laetiporus sulphureus (Bull.) Murrill, some coprophilous mushrooms like Coprinus comatus (O.F. Müll.) Pers. and the post-fire mushroom Morchella importuna M. Kuo, O'Donnell \& T.J. Volk have been shown to also be able, although to a lesser extent, to produce oxidative enzymes for lignin degradation [13,15-17]. Most of these mushrooms are edible and/or have medicinal proprieties and have been successfully cultivated [18-20]. Coprinus comatus is also cultivated on a biogas residue mixture and is patent-protected [21]. Only M. importuna has begun to be cultivated recently, predominately in open fields in China [22].

In the past, several analytical approaches were carried out to study the ability of fungal species to decompose lignin. Since lignin is closely associated to cellulose and hemicellulose, its separation is considered problematic, because the extraction procedures take time and lead to chemical and structural changes caused by condensation and oxidation reactions [23]. There are two main conventional techniques to separate lignin from hemicellulose and cellulose: the first is to remove cellulose and hemicellulose, leaving most of the lignin as a solid residue, and the second is to extract lignin using fractionation procedures, leaving the other components [24]. As a result, the original structural characteristics of lignin may be missing.

Attenuated total reflectance-Fourier transform infrared (ATR-FTIR) spectroscopy is a nondestructive technique that has been successfully used for detecting chemical compounds present in complex mixtures, because each molecule is characterized by a specific spectrum. Pandey and Pitman [25] and Gupta et al. [26] have widely used this technique to monitor the chemical variations that occur during wood degradation by chemical and biological treatments. However, some spectra may appear poorly resolved due to the existence of highly overlapping and hidden peaks. Consequently, it is not possible to assign specific peaks to the vibrations of specific functional groups. In such cases, the application of a curve-fitting analysis has become an important tool for qualitative and quantitative analyses of IR spectra [27].

In this context, the main goal of the project was to use mushroom cultivation for degrading the ligninolytic fraction of digestate. Several edible and medicinal mushroom species were tested, and their ability to degrade the lignin fraction was assessed by using ATR-FTIR spectroscopy. 


\section{Results}

\subsection{In Vitro Mycelial Growth and Elemental Analysis of $C$ and $N$ of Substrates}

Ganoderma lucidum, G. resinaceum, L. sulphureus and L. edodes did not grow or grew very slowly on the digestate, whereas C. aegerita, M. importuna, P. cornucopiae and P. ostreatus grew similarly or significantly more (P. ostreatus) on the corn digestate (CD) compared to the straw (Table S1 and Figure S1). For this reason, the C and N content and ATR-FTIR spectra were carried out only on the latter four species. Coprinus comatus was also included, because, recently, a substrate containing biogas residues has been patented for its cultivation [21].

Table 1 shows the $\mathrm{C}$ and $\mathrm{N}$ values determined in CD, corn digestate $50 \%$-wheat straw 50\% (CD-WS) and wheat straw (WS) before inoculation (control) and after $12 \mathrm{~d}$ of mycelial growth. The $\mathrm{C}$ percentage of CD-WS showed no intermediate value due to the high chemical complexity of CD. The C content of substrates inoculated with several mushrooms showed no considerable variation (Table 1). The C content was significantly lower in C. aegerita on CD and significantly higher in C. comatus, M. importuna, P. cornucopiae and P. ostreatus on WS than in the untreated substrates (control).

Table 1. Total content of $\mathrm{C}$ and $\mathrm{N}$ on different substrates before inoculation with the fungi studied (control) and after a 12-d period of mycelium growth following inoculation.

\begin{tabular}{|c|c|c|c|c|c|c|}
\hline \multirow{3}{*}{ Species } & \multicolumn{6}{|c|}{ Substrates } \\
\hline & \multicolumn{2}{|c|}{$\mathrm{CD}$} & \multicolumn{2}{|c|}{ CD-WS } & \multicolumn{2}{|c|}{ WS } \\
\hline & $\mathrm{C}(\%)$ & N (\%) & $\mathrm{C}(\%)$ & N (\%) & $\mathrm{C}(\%)$ & N (\%) \\
\hline Control & $39.07 \pm 0.07$ & $1.59 \pm 0.01$ & $39.57 \pm 1.04$ & $1.18 \pm 0.005$ & $36.26 \pm 0.005$ & $1.16 \pm 0.04$ \\
\hline Cyclocybe aegerita & $38.67 \pm 0.02 * *$ & $1.54 \pm 0.04$ & $39.18 \pm 0.004$ & $1.13 \pm 0.01 *$ & $37.93 \pm 0.99$ & $0.62 \pm 0.008^{* *}$ \\
\hline Coprinus comatus & $39.60 \pm 0.47$ & $1.51 \pm 0.07$ & $39.43 \pm 0.18$ & $1.15 \pm 0.01$ & $39.55 \pm 0.27 * *$ & $0.67 \pm 0.01^{* *}$ \\
\hline Morchella importuna & $38.94 \pm 0.04$ & $1.55 \pm 0.04$ & $39.81 \pm 0.29$ & $1.08 \pm 0.02^{* *}$ & $39.86 \pm 0.79 *$ & $0.68 \pm 0.02 * *$ \\
\hline Pleurotus cornucopiae & $39.07 \pm 0.05$ & $1.37 \pm 0.10$ & $38.80 \pm 0.32$ & $1.20 \pm 0.04$ & $38.52 \pm 0.05^{* *}$ & $0.61 \pm 0.01 * *$ \\
\hline Pleurotus ostreatus & $39.86 \pm 0.59$ & $1.59 \pm 0.05$ & $39.39 \pm 0.96$ & $0.81 \pm 0.007^{* *}$ & $39.61 \pm 0.68 * *$ & $0.57 \pm 0.009^{* *}$ \\
\hline
\end{tabular}

The nitrogen content on WS inoculated with the different mushrooms was generally significantly lower than the control (Table 1). These changes led to a significant increase in the C/N ratio on WS, which was 31 in the control and ranged from 59 to 69 after the fungal growth (Table S2). On the CD substrate, there were no significant differences between treatments, although a slight decrease of $\mathrm{N}$ was apparent in the presence of $C$. comatus and $P$. cornucopiae (Table 1). In the CD-WS substrate, only $C$. aegerita, $P$. ostreatus and $M$. importuna significantly decreased the $\mathrm{N}$ content. No variation was observed for the other species. Considering the $\mathrm{C} / \mathrm{N}$ ratio, no variation was observed on the $\mathrm{CD}$, while on the CD-WS, the C/N ratio was 34 in the control and 49 after the growth of P. ostreatus (Table S2).

\subsection{ATR-FTIR of Substrates After In Vitro Mycelial Growth}

Figure 1 shows the ATR-FTIR spectra of the substrates (CD, CD-WS and WS) after $12 \mathrm{~d}$ of mycelial growth with different mushrooms species. The ATR-FTIR spectra clearly showed a significant structural variation of the main functional groups in the region between $1800-1200 \mathrm{~cm}^{-1}$, in which many clearly defined peaks provided information on their modification during degradation.

The major peaks can be listed as follows: $1740 \mathrm{~cm}^{-1}$ is ascribed to unconjugated $\mathrm{C}=\mathrm{O}$ in xylans (hemicellulose) or in the heterocyclic cellulosic rings [28]; $1727 \mathrm{~cm}^{-1}$ is due to H-bonded acid/ketone carbonyl groups; $\sim 1645 \mathrm{~cm}^{-1}$ is assigned to $\mathrm{C}=\mathrm{O}$ stretching in conjugated ketones, water and amide I (proteins); 1590 and $1510 \mathrm{~cm}^{-1}$ are attributed to aromatic skeletal vibrations $(\mathrm{C}=\mathrm{C})$ and aromatic breathing in lignin, respectively [29-31]; 1547 $\mathrm{cm}^{-1}$ is related to amide II (proteins); $1457 \mathrm{~cm}^{-1}$ is due to $\mathrm{C}-\mathrm{H}$-bending in lignin and hemicelluloses and 1423 and $1370 \mathrm{~cm}^{-1}$ are assigned to $\mathrm{CH}_{2}$ and $\mathrm{CH}_{3}$-bending vibrations, respectively. These bands are typical of the mixture of both crystalline and 
amorphous cellulose [32]; $1318 \mathrm{~cm}^{-1}$ is attributed to C-H bending in crystallized cellulose I [33], and $\sim 1240 \mathrm{~cm}^{-1}$ is assigned to the syringyl ring in lignin and C-O stretching in xylan of hemicellulose [25,34].
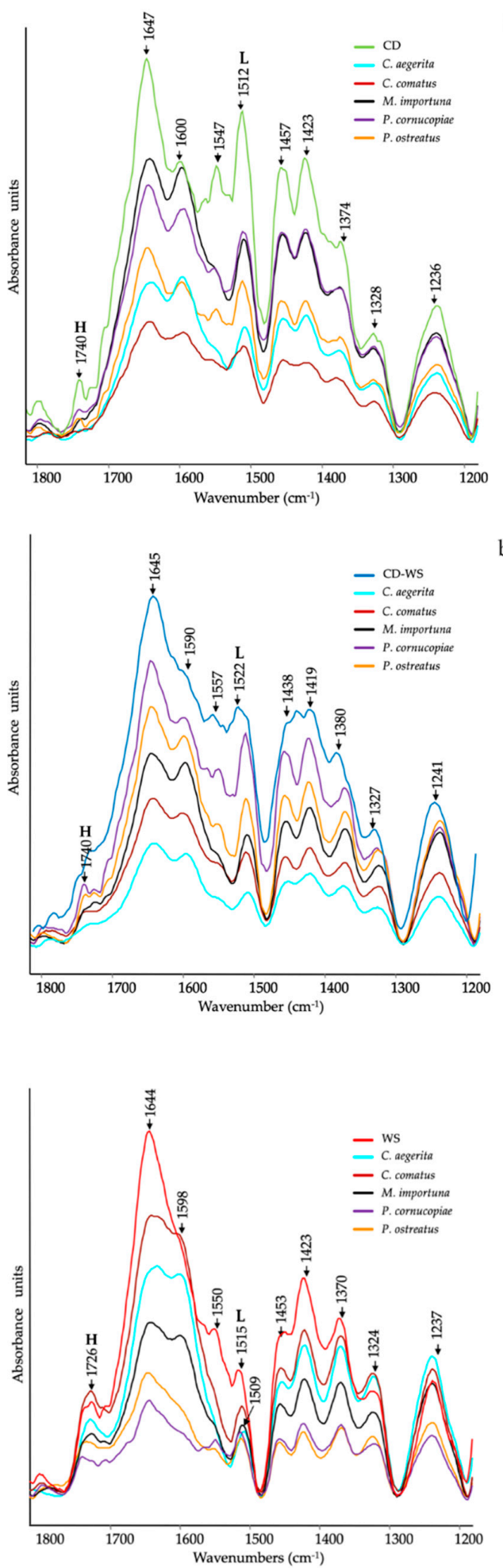

Figure 1. Attenuated total reflectance-Fourier transform infrared (ATR-FTIR) spectra of (a) corn digestate (CD, green line), (b) corn digestate 50\%-wheat straw 50\% (CD-WS, blue line) and (c) wheat straw (WS, red line) after $12 \mathrm{~d}$ of mycelial growth of Cyclocybe aegerita (cyan line), Coprinus comatus (dark red line), Morchella importuna (black line), Pleurotus cornucopiae (purple line) and Pleurotus ostreatus (orange line). $\mathbf{H}=$ hemicellulose and $\mathbf{L}=$ lignin (as references for lignin: [29-31]). 
In more detail, the ATR-FTIR spectra of the CD substrate after mycelium growth, as compared to untreated CD (Figure 1a), showed a significant decrease in the relative intensity of the bands assigned to hemicellulose $\left(1740 \mathrm{~cm}^{-1}\right.$ and $\left.1236 \mathrm{~cm}^{-1}\right)$, proteins $\left(1647 \mathrm{~cm}^{-1}\right.$ and $\left.1547 \mathrm{~cm}^{-1}\right)$ and lignin $\left(1600 \mathrm{~cm}^{-1}\right.$ and $\left.1512 \mathrm{~cm}^{-1}\right)$. All these compounds changed in relation to the inoculated mushroom species.

In some instances, ester bands in hemicellulose have disappeared in CD treated with C. aegerita and C. comatus, as well as amide (II) in proteins, as supported by the slight reduction in total nitrogen (Table 1). Concerning the lignin bands $\left(1600 \mathrm{~cm}^{-1}\right.$ and $\left.1512 \mathrm{~cm}^{-1}\right)$, they progressively decreased in the series: C. comatus $<$ C. aegerita $<$ P. ostreatus $<$ P. cornucopiae $<M$. importuna.

In the case of the ATR-FTIR spectra of the CD-WS substrate after mycelium growth, a slight difference compared to the untreated substrate was observed (Figure 1b). The relative intensities of hemicellulose bands considerably decreased in the substrate treated with C. aegerita and C. comatus, as well as in the protein bands $\left(1645 \mathrm{~cm}^{-1}\right.$ and $\left.1557 \mathrm{~cm}^{-1}\right)$, although no correspondence with the total $\mathrm{N}$ was found. Regarding the peaks taken as a reference of lignin $\left(1590 \mathrm{~cm}^{-1}\right.$ and $\left.1522 \mathrm{~cm}^{-1}\right)$, they progressively decreased in the series: $C$. aegerita $<$ C. comatus $<M$. importuna $<$. ostreatus $<P$. cornucopiae.

Figure 1c showed the ATR-FTIR spectra of the WS substrate. As already observed on CD and CD-WS, the intensity of the hemicellulose bands $\left(1726 \mathrm{~cm}^{-1}\right.$ and $\left.1237 \mathrm{~cm}^{-1}\right)$ decreased in treatments with P. cornucopiae and P. ostreatus. As regards to the amide bands, a considerable reduction appeared in all treatments, as also supported by the variation of the total $\mathrm{N}$ (Table 1). The intensity of the band at $1509 \mathrm{~cm}^{-1}$ (lignin) was significantly reduced in all spectra, although it was more consistent in P. ostreatus and P. cornucopiae.

\subsection{Fruiting Body Production}

For the cultivation test, C. aegerita, P. cornucopiae and P. ostreatus were used. The choice was made based on the results obtained from the measurements of the mycelial growth rate on the CD (Table S1) and the commercial potential of the species. The species M. importuna, even though it has rapid development in in vitro tests, was not selected for cultivation trials, as its production of fruiting body is still difficult in controlled conditions [35].

The different species used during the cultivation tests showed a fruiting body production (Figure 2a and Figure S2) and a biological efficiency similar in the different substrates used. Although there were no statistically significant differences between substrates, P. ostreatus grown on CD exhibited a fruiting body production and a biological efficiency apparently higher than poplar chips-wheat straw (PC-WS) or wheat straw-wheat bran (WS-WB). On the other hand, P. cornucopiae showed not significantly higher production and biological efficiency compared to the WS (Figure 2a,b).
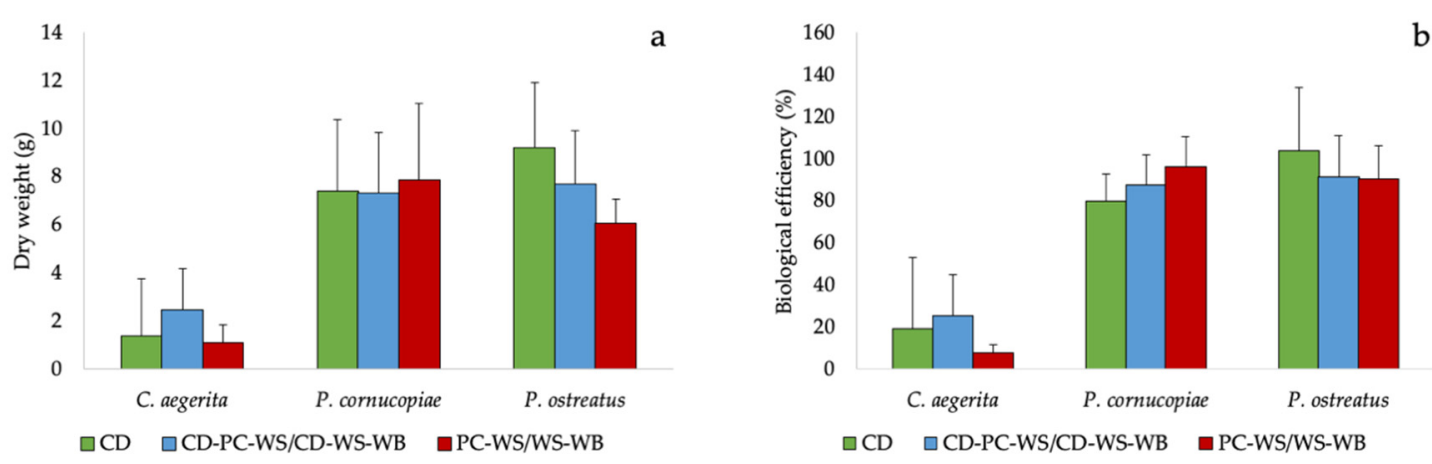

Figure 2. (a) Fruiting body production and (b) biological efficiency of the tested mushrooms species on the $\mathrm{CD}$ and on corn digestate-poplar chips-wheat straw (CD-PC-WS) or corn digestate-wheat straw-wheat bran (CD-WS-WB) and on PC-WS/WS-WB. 


\subsection{Structural Evaluation of Substrates after Fruiting Body Production}

Gaussian curve-fitting procedure applied to the substrates ATR-FTIR spectra (CD, corn digestate-wheat straw-wheat bran (CD-WS-WB) and wheat straw-wheat bran (WS-WB)) after production of the fruiting body provided additional quantitative results. The area under the entire band was considered as $100 \%$, and each component after fitting was expressed as a percent area. Cyclocybe aegerita was not included in the spectroscopic analyses, because its mycelium did not completely colonize the substrate and the fruiting body production was low.

The percentage area of each functional group can be considered representative of the structural modification as a consequence of the fruiting body production.

Histograms of the percentage area of each considered band of CD, CD-WS-WB and WS-WB substrate spectra of untreated and after the fruiting body production of P. ostreatus and P. cornucopiae are shown in Figure 3. The ester in hemicellulose $\left(1740 \mathrm{~cm}^{-1}\right)$ in the untreated CD accounts for $1.4 \%$, while it completely disappeared in the substrates with $P$. cornucopiae and, at the same time, represented $7.1 \%$ with $P$. ostreatus.
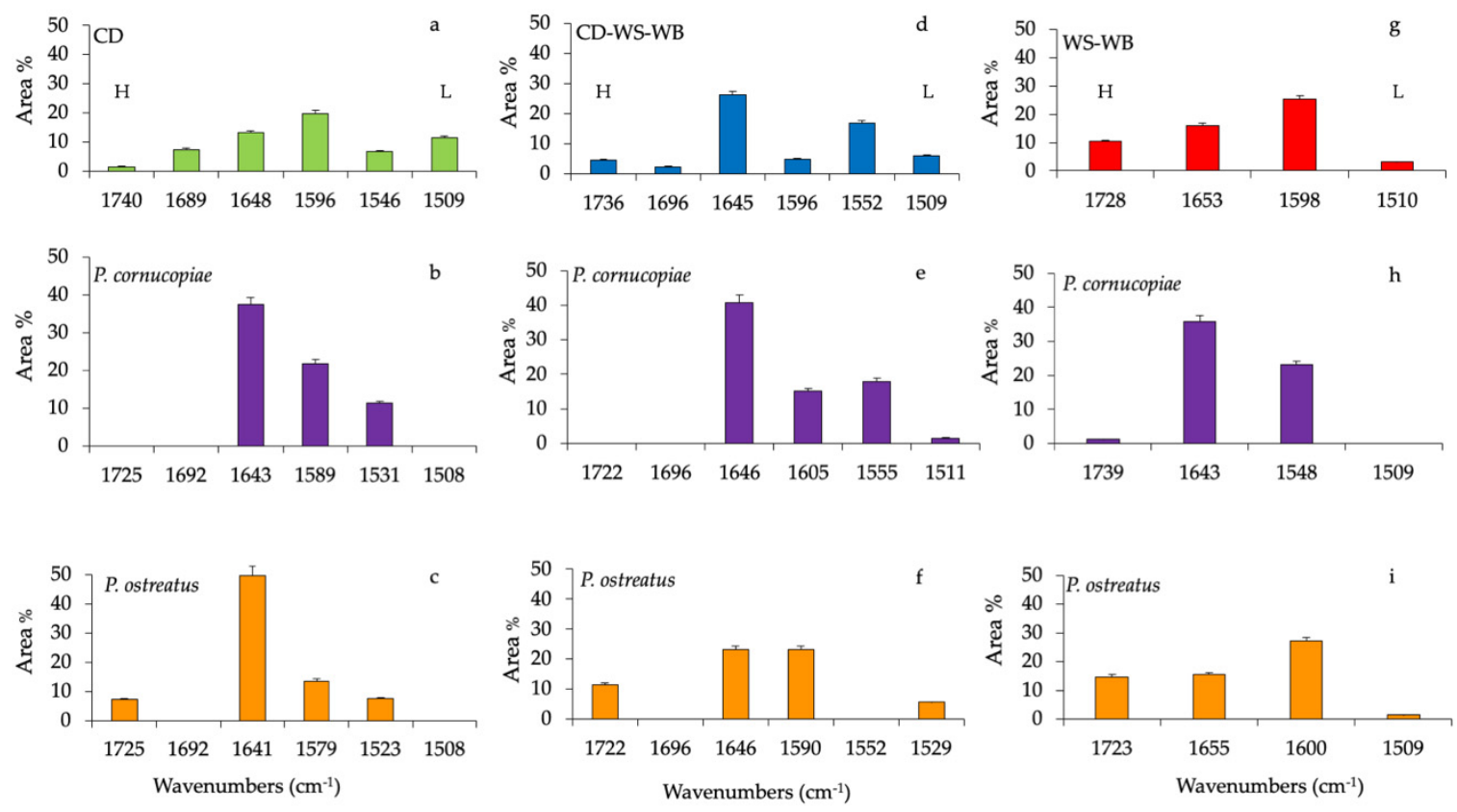

Figure 3. Histograms of peak areas (\%) processed by using a curve fitting in the region from 1800 to $1200 \mathrm{~cm}^{-1}$. The best-fitting parameters were determined by the minimization of the reduced chi-square $\left(\chi^{2}\right)$ and coefficients of determination $\left(\mathrm{R}^{2}\right)$ that ranged from 0.990 to 0.980 . The bar corresponds to the standard error. (a) Corn digestate (CD, green), (d) corn digestate-wheat straw-wheat bran (CD-WS-WB, blue) and (g) wheat straw-wheat bran (WS-WB, red) correspond to untreated substrates. Substrates after the fruiting body production of $P$. cornucopiae (purple) on (b) CD, on (e) CD-WS-WB, on (h) WS-WB and of $P$. ostreatus (orange) on (c) CD, on (f) CD-WS-WB and on (i) WS-WB. $\mathbf{H}=$ hemicellulose and $\mathbf{L}=$ lignin (as references for lignin: [29-31]).

The band at $1680 \mathrm{~cm}^{-1}$ ( $\mathrm{C}=\mathrm{O}$-conjugated ketone stretch) accounted for $7.3 \%$ and was only present on untreated CD (Figure 3a). The protein content in the CD was evaluated by amide I $\left(1648 \mathrm{~cm}^{-1}\right)$ and amide II $\left(1546 \mathrm{~cm}^{-1}\right)$, which accounted for $11.3 \%$ and $6.5 \%$, respectively. In the composition of anaerobic digestate, the presence of bioactive substances such as proteins or amino acids was clearly identified [36]. Besides, the variation of the band at $1648 \mathrm{~cm}^{-1}$ may be also due to the deformation vibration of adsorbed water [25].

On the contrary, both amide groups increased considerably by $49.8 \%$ and $7.5 \%$ in the substrate, with P. ostreatus at $37.4 \%$ and $11.3 \%$ with P. cornucopiae, respectively. In the CD substrate, lignin bands 
$\left(\sim 1580 \mathrm{~cm}^{-1}\right.$ and $\left.1508 \mathrm{~cm}^{-1}\right)$ contributed to $20 \%$ and $11.5 \%$, respectively. After the fruiting body production of $P$. ostreatus and P. cornucopiae, the band at $1508 \mathrm{~cm}^{-1}$ disappeared completely, while the band at $\sim 1580 \mathrm{~cm}^{-1}$ accounted for $13.5 \%$ with P. ostreatus and $21.8 \%$ with P. cornucopiae (Figure $3 \mathrm{~b}, \mathrm{c}$ ). Variations in lignin peaks would indicate the opening of the lignin reticles through the removal of lignin subunits.

In the untreated CD-WS-WB substrate (Figure $3 \mathrm{~d}$ ), the $\mathrm{CD}$ presence could be recognized from the $\mathrm{C}=\mathrm{O}$ conjugated ketone $\left(1690 \mathrm{~cm}^{-1}\right)$, amide I $\left(1645 \mathrm{~cm}^{-1}\right)$ and amide II $\left(1550 \mathrm{~cm}^{-1}\right)$ bands. All these functional groups were, respectively, $2.2 \%, 26.2 \%$ and $16.7 \%$. As previously mentioned in the CD substrates, the band at $1690 \mathrm{~cm}^{-1}$ disappeared with P. ostreatus and P. cornucopiae (Figure 3e,f). In the substrate with P. cornucopiae, the contents of amide I and amide II were, respectively, $40.8 \%$ and $17.9 \%$. The high value of amide I may also be due to the influence of the absorbed water [25]. On the other hand, in P. ostreatus, amide I decreased by $23 \%$, while amide II was missing. The ester in hemicellulose $\left(\sim 1730 \mathrm{~cm}^{-1}\right)$ in the untreated CD-WS-WB accounted for $4.5 \%$; on the contrary, in P. ostreatus, it increased by $11.4 \%$, and it was missing in P. cornucopiae. Regarding the lignin in the untreated substrate $\left(\sim 1596 \mathrm{~cm}^{-1}\right.$ and $\left.1509 \mathrm{~cm}^{-1}\right)$, it accounted for $4.8 \%$ and $6.0 \%$, respectively.

As a result of the production of fruiting bodies, lignin components with P. ostreatus changed only for the band at $1590 \mathrm{~cm}^{-1}$ by $23 \%$, but no variation of the band at $1529 \mathrm{~cm}^{-1}(5.6 \%)$ was observed. In the substrates with P. cornucopiae, the band at $1605 \mathrm{~cm}^{-1}$ was around $15 \%$, and the band at $1511 \mathrm{~cm}^{-1}$ was $1.5 \%$. The delignification process in the substrate with P. ostreatus led to an increase in aromatic rings $\left(1590 \mathrm{~cm}^{-1}\right)$ and to the formation of new carbonyl groups in hemicellulose esters [29]. In the substrates with P. cornucopiae, lignin degradation was associated with the disappearance of the bands at $1509 \mathrm{~cm}^{-1}$ arising from the aromatic skeletal vibration of the benzene ring and, also, that of hemicellulose.

In the untreated WS-WB substrate (Figure 3g), the ester in hemicellulose was $10.3 \%$, and the lignin accounted for $25 \%$ and $3 \%$, respectively. After the fruiting body production of P. cornucopiae (Figure $3 \mathrm{~h}$ ) and P. ostreatus (Figure 3i), the hemicellulose accounted for $1.3 \%$, and $14.7 \%$, respectively. The lignin was $27 \%\left(1600 \mathrm{~cm}^{-1}\right)$ and $1.6 \%\left(1508 \mathrm{~cm}^{-1}\right)$ with P. ostreatus and $23 \%\left(1548 \mathrm{~cm}^{-1}\right)$ with P. cornucopiae. As already observed in the CD-WS-WB substrate, the delignification and degradation process involved the same compounds.

\section{Discussion}

The anaerobic digestate from biogas plants has considerable operational and environmental drawbacks caused by the releasing greenhouse gases $\left(\mathrm{NH}_{3}, \mathrm{CO}_{2}\right.$ and $\left.\mathrm{N}_{2} \mathrm{O}\right)$ and by the presence of nondigested organic compounds [37-39]. The management of digestate with mushrooms that can decay the lignocellulosic component is creating a new scenario in biomass recycling in agriculture [12].

In this work, the mycelial growth in vitro and the biological efficiency of different mushroom species cultivated on CD-based substrates were explored. The structural modifications, as a result of the growth of different mushroom species, were monitored by using ATR-FTIR spectroscopy.

The results of the tests in the Petri dishes (Table S1) showed that P. ostreatus and M. importuna exhibited a higher growth rate on CD than on WS used as a control. Although these species are characterized by varying nutritional needs, the alkaline $\mathrm{pH}$ of the digestate has encouraged the growth of M. importuna [40]. Furthermore, for P. ostreatus, the higher nitrogen content in the CD than in the WS has contributed to a faster development, as already demonstrated in other studies [41,42] where a higher yield was obtained with straw that was enriched with nitrogen-rich plant supplements. As already shown by Santi et al. [43], the CD substrate would be suitable for the growth of lignivorous species such as Pleurotus spp. compared to digestates obtained from other biomasses.

The changes in substrate compositions in terms of elemental C and N (Table 1) after the mycelial growth in Petri dishes have shown an overall increase in the $\mathrm{C} / \mathrm{N}$ ratio in the CD-WS and, especially, in the WS. Similar results were previously obtained in other works after 12 days of mycelial growth [44].

The variations observed in the WS may be due to the low $\mathrm{C} / \mathrm{N}$ ratio of the durum wheat straw used in this trial. However, the biomasses from agrowastes are characterized by a great variation of 
the $\mathrm{N}$ amount and, thus, of the carbon-to-nitrogen $(\mathrm{C} / \mathrm{N})$ ratios. A considerable variation in the $\mathrm{C} / \mathrm{N}$ ratio may also be assumed when the biomass is stored under aerobic conditions, as in our experiment, and consequently, an undesirable decomposition is expected. It was also reported that residues from crops with a $\mathrm{C} / \mathrm{N}$ ratio below 30 should lead to a net $\mathrm{N}$ mineralization, while residues with a $\mathrm{C} / \mathrm{N}$ ratio above 30 should promote immobilization [45].

In most cases, fungi are stimulated to incorporate $\mathrm{N}$ into proteins when the $\mathrm{C}$ source is lower than the $\mathrm{N}$ source. This could explain the significant reduction of $\mathrm{N}$ and the variation of amide bands in the FT-IR spectra of WS after mycelial growth.

The increase in total $\mathrm{C}$ may be explained as a combination of depolymerization of the lignocellulosic component and conversion of the labile $\mathrm{C}$ into the mycelial biomass. Generally, mushrooms in the early stages of lignin decomposition degrade it into a more labile component, and consequently, an apparent increase in the recalcitrant fraction may be observed [46]. All these variations are associated to structural alterations, as it was observed in our 12 days-study [46]. The structural variations of the substrates were dependent on the biomass type and mushroom species. After 12 days of mycelial growth, all tested species showed to be able to initiate depolymerization and, subsequently, decay the lignocellulosic component of CD. For example, in this early stage, C. aegerita and C. comatus degraded hemicellulose $\left(1740 \mathrm{~cm}^{-1}\right)$ and proteins $\left(1647 \mathrm{~cm}^{-1}\right.$ and $\left.1547 \mathrm{~cm}^{-1}\right)$, as demonstrated by the significant decrease in the relative intensity of the bands. Concerning lignin decay $\left(1600 \mathrm{~cm}^{-1}\right.$ and $\left.1512 \mathrm{~cm}^{-1}\right)$, M. importuna and both Pleurotus spp. were more active compared to C. comatus and C. aegerita. Recent studies carried out on $M$. importuna genome have shown that the laccase-like multicopper oxidase (LMCO) gene was present in the genome and may therefore support the observed effects [17].

In the case of the CD-WS, the substrate modifications were very similar to those observed for the $\mathrm{CD}$ with the involvement of $C$. aegerita and C. comatus for hemicellulose and protein degradation and both Pleurotus and M. importuna for lignin. As for the WS substrate, all species were able to modify it-in particular, P. cornucopiae and P. ostreatus, which attacked lignin more readily than hemicellulose.

Cultivation trials conducted on C. aegerita, P. cornucopiae and P. ostreatus highlighted the suitability of CD for the cultivation of edible mushrooms. Their biological efficiency on CD (19\%, 80\% and 103.3\%, respectively) was in-line with those previously obtained on other substrates [42,47]. Pleurotus ostreatus and P. cornucopiae showed good biological efficiency, proving capable of exploiting digestate based substrates, as shown in previous studies conducted on Pleurotus spp. [48-52]. In particular, P. ostreatus grown on the CD exhibited a higher production of fruiting bodies (34\% more) and biological efficiency (9\% more) than the WS, the most used substrate for its cultivation [20,53,54]. The CD allowed to obtain a good fruiting body's production of Pleurotus without the addition of the WB for its high N content (Table 1). In fact, the WB is commonly added to the WS as a nitrogen supplement for increasing the production [55].

Results on spent substrates after the production of the fruiting bodies showed a different decay of lignocellulosic constituents depending on the mushroom species. The most important change was observed for hemicellulose and lignin, which were completely decayed in the spent substrate of P. cornucopiae. Results showed that P. cornucopiae performed an efficient degradation of the lignocellulose component, particularly with only the digestate. Nevertheless, the constant presence of hemicellulose residues in all spent substrates of $P$. ostreatus was unexpected, although an increase in the cellulose content after mushroom growth on the WS was also reported [43,56]. Moreover, lignin decomposed in the CD and WS-WB-spent substrates. That is coherent with the activity of white-rot mushrooms. These mushrooms generate a mixture of ligninolytic enzymes that catalyze the oxidation of aromatic substrates by producing aromatic radicals and modifying the structure of biomasses that contain lignocellulose and lignin [51]. White-rot mushrooms carry out delignification through two main patterns: nonselective delignification or selective delignification [57]. In nonselective delignification, the degradation of lignin, cellulose and hemicellulose occurs simultaneously. Selective delignification, typical of different species of fungi, including Pleurotus spp., involves the degradation of lignin and 
hemicellulose before the attack of cellulose [57-59]. However, the chemical analyses in this study revealed a nonselective delignification for our strain of $P$. cornucopiae.

After lignin removal, spent substrates may be suitable for biogas production, as the materials are biologically predigested and are more available for bacterial degradation through anaerobic digestion [60-62]. Several works have underlined that pretreating different lignocellulosic biomasses with Pleurotus spp. before feeding them into the biogas plant leads to higher biogas production compared to the untreated biomasses with mushrooms [63-66]. Additionally, soil fertilization with the spent digestate obtained after mushroom growth produces benefits to the soil microbial communities from the availability of the released nutrients [67]. Consequently, the effects of fungi can be a powerful protective tool against soil fungal diseases [68].

The results obtained confirm the possibility to economically utilize the digestate for mushroom cultivation. Moreover, lignin removal by mushroom mycelium improves the degradation of hemicellulose and cellulose, and this is one of the strategies needed to improve its further utilization as fertilizer and opens up the possibility to obtain new biobased products.

\section{Materials and Methods}

\subsection{Substrates}

The corn digestate was obtained from a biogas plant that is located in Malalbergo (Bologna, Italy). The biogas plant can be classified as "single-phase, two-stage" and is designed to work in semi-dry conditions (total solid 13\%) and is fed exclusively with energy crops (maize, sorghum and triticale silage). This plant can be considered to be of compact dimension compared to other technical solutions with the same productive capacity $\left(4100 \mathrm{~m}^{3}\right.$ of volume for $1 \mathrm{MW}$ of installed electrical power), due to the ability to develop the process with high concentrations of substrate. The average biomass consumption is approximately $18,500 \mathrm{~T} /$ year for a biogas production of $4,050,000 \mathrm{~m}^{3}(8,500,000 \mathrm{kWh} /$ year of gross renewable electric energy production). The mean hydraulic retention time (HRT) of the biomass is 70 days - after which, the digestate is separated into solid and liquid fractions through a mechanical screw separator. The solid digestate (SD) production is $2500 \mathrm{~T} / \mathrm{year}$ and, after separation, is stored in trench silos similar to those commonly used for silomais. The liquid digestate $(10,000 \mathrm{~T} / \mathrm{year})$ is stocked in a specifically covered tank. The SD used in this work was produced in February and collected as soon as it fell out of the mechanical separator.

Durum wheat straw and Populus spp. chips were kindly provided by the Cadriano farm of the University of Bologna. In particular durum wheat straw was used in the farm to produce compost, and it was stored under aerobic conditions in the field. All raw materials were dehydrated at room temperature and kept in the stove at $60^{\circ} \mathrm{C}$ for $24 \mathrm{~h}$. They were subsequently crushed with scissors and a manual grinder into fragments smaller than $0.5 \mathrm{~cm}$ and autoclaved at $121 \pm 1{ }^{\circ} \mathrm{C}$ for $60 \mathrm{~min}$ to prevent any contamination during their storage. The dried raw materials were stored in a desiccator at $22^{\circ} \mathrm{C}$.

Organic soft wheat bran and Alabastrine gypsum $\left(\mathrm{CaSO}_{4} \cdot 2 \mathrm{H}_{2} \mathrm{O}\right.$, lab grade) were used for the mushroom cultivation trials.

\subsection{Mushrooms Cultures and Mycelial Growth Rate Evaluation}

Experimental trials were carried out by using 9 strains of Basidiomycetes (C. aegerita, C. comatus, G. lucidum, G. resinaceum, L. sulphureus, P. cornucopiae, P. ostreatus and S. commune) and Ascomycetes (M. importuna) isolated from fruiting bodies collected in the wild; the L. edodes (Basidiomycete) strain was brought by the Fungal Institute of Jinxiang (Shan-dong province, China) (Table S1).

The mycelial pure cultures were stored in the Mycological and Applied Botany Laboratory (CMI-UNIBO strain collection) of the Department of Agricultural and Food Sciences (DISTAL), University of Bologna (Italy).

All the isolates were kept on potato dextrose agar (PDA, Difco, Detroit, MI, USA) half-strength, at $22 \pm 1{ }^{\circ} \mathrm{C}$ in darkness and subcultured every two months. 
For the mycelial growth rate evaluation, plugs of $10 \mathrm{~mm}$ in diameter were taken by 15-day-old colonies of each species and inoculated in the center of a 9-cm sterilized Petri dish previously filled with $15 \mathrm{~g}$ of three different substrates at $80 \%$ humidity: CD, CD-WS $(1: 1, w / w)$ and WS as the control. Five replicates were made for each combination of species and substrate. All plates were incubated at $22 \pm 1{ }^{\circ} \mathrm{C}$ in darkness. The mushroom growth was assessed by measuring the diameter of the colony along two preset diametrical lines every day. Radial daily growth rate (rGR) was calculated during the first 3 days of the exponential phase as:

$$
\mathrm{rGR}=\frac{\left(\mathrm{D}_{1}-\mathrm{D}_{0}\right) / 2}{\left(\mathrm{t}_{1}-\mathrm{t}_{0}\right)} \times 24
$$

where $D_{0}$ and $D_{1}$ are the colony diameter during the exponential growth phase at time $t_{0}$ and $t_{1}$, respectively [69] (modified).

\subsection{Inoculum Preparation and Cultivation Trials}

Cultivation tests were carried out for C. aegerita, P. cornucopiae and P. ostreatus. The grain spawn was prepared by inoculating 15-day-old mycelial plugs in glass tubes containing sorghum kernels and distilled water in a 1:2 (v/v) ratio previously sterilized at $121 \pm 1^{\circ} \mathrm{C}$ for $20 \mathrm{~min}$. For each species-substrate combination, 5 replicates were prepared. The tubes were incubated in the dark at $22 \pm 1{ }^{\circ} \mathrm{C}$ for 30 days. The spawn was ready when the mycelium had colonized all the kernels.

Three different solid substrates were tested: a digestate based substrate ( $97 \%$ corn digestate), a substrate with $48 \%$ of digestate and as a control and a substrate based on poplar chips (PC) or WS according to the mushroom substrates preferences [20,55] (Table 2). Homogeneous substrate mixtures were prepared by mixing component materials based on their dry weight $(w / w)$.

Table 2. Composition of the substrates used for cultivation trials.

\begin{tabular}{ccc}
\hline Species & Substrates and Mixing Ratio ${ }^{1}$ & Code \\
\hline P. cornucopiae & $97 \%$ CD:3\% gypsum & CD \\
P. ostreatus & $48 \%$ CD: $46 \%$ WS:3\% WB:3\% gypsum & CD-WS-WB \\
& $92 \%$ WS:5\% WB:3\% gypsum (control) & WS-WB \\
C. aegerita & $97 \%$ CD:3\% gypsum & CD \\
& $48 \%$ CD: $44 \%$ PC:5\% WS:3\% gypsum & CD-PC-WS \\
& $88 \%$ PC: $9 \%$ WS:3\% gypsum (control) & PC-WS
\end{tabular}

\footnotetext{
1 dry weight $(w / w)$. Abbreviations: CD—corn digestate; WS—wheat straw; WB—wheat bran and PC—poplar wood chips.
}

The substrates were inserted into autoclavable polypropylene transparent bags $(20 \times 30 \mathrm{~cm})$. Dried mixed substrates (1.5 L per bag: $120 \mathrm{~g}$ for CD, $110 \mathrm{~g}$ for CD-WS-WB and $100 \mathrm{~g}$ for WS-WB and 160 for CD-PC-WS and $200 \mathrm{~g}$ for PC-WS) were moistened with $500 \mathrm{~mL}$ (per bag) of distilled water for $24 \mathrm{~h}$, and the excess of water was removed by squeezing the bags.

Bags were closed with a hydrophobic cotton cap, autoclaved at $121 \pm 1^{\circ} \mathrm{C}$ for $60 \mathrm{~min}$ and inoculated with grain spawn by opening the bag and inserting the inoculum inside of it ( $45 \mathrm{~g}$ per bag), mixing the inoculum with the substrate and incubating it in the darkness at $22 \pm 1{ }^{\circ} \mathrm{C}$ until complete colonization of the substrate. For each species-substrate combination, five bags were prepared. Mycelial bag colonization was evaluated.

After 20 or 35 days of mycelial growth of the two Pleurotus species and C. aegerita, respectively, the bags were moved to a climatic chamber with a temperature of $19 \pm 1^{\circ} \mathrm{C}$ during the day and $14 \pm 1{ }^{\circ} \mathrm{C}$ during the night, relative humidity between $80 \%$ and $85 \%$ and $12-\mathrm{h}$ light/dark photoperiod with a light intensity of $700 \pm 100$ lux. The mature fruiting bodies were collected for 3 months; the fresh weight 
was recorded for the evaluation of biological efficiency [70]; then, they were dried in a stove at $65^{\circ} \mathrm{C}$ for $24 \mathrm{~h}$ and weighed. Biological efficiency was calculated as:

$$
\text { Biological efficiency }(\%)=\frac{\text { fresh weight of mushrooms }}{\text { dry weight of substrate }} \times 100
$$

\subsection{Chemical Analyses}

In order to evaluate changes in the chemical composition of the different substrates before and after the 12 days of mycelial growth, the elemental analysis of $\mathrm{C}$ and $\mathrm{N}$ was carried out. Five replicates of each substrates before and after inoculation were collected from the Petri dishes. All samples were mixed, washed five times with distilled water, dried in a stove at $35^{\circ} \mathrm{C}$ for $48 \mathrm{~h}$ and crushed in a ball mill (RETSCH MM 400, Haan, Germany) to produce a homogeneous mixture of each material. The elemental analysis was carried out using Flash EA 2000 Elemental Analyzer (Thermo Scientific, Bremen, Germany) on $2 \mathrm{mg}$ and performed on triplicate samples.

\subsection{Attenuated Total Reflectance-Fourier Transform Infrared (ATR-FTIR) Spectroscopy Analysis}

The FTIR spectra were recorded by using an ALPHA FTIR spectrometer (Bruker Optics, Ettlingen, Germany) equipped with a diamond crystal ATR (attenuated total reflectance) device. The substrates were analyzed after 12 days of in vitro mycelial growth and after the fruiting bodies production (4 months after inoculation) were analyzed. Each sample was deposited on the surface of the crystal, and the spectra were acquired against a pre-established background by averaging 64 scans from 4000 to $400 \mathrm{~cm}^{-1}$ at a $4-\mathrm{cm}^{-1}$ resolution. Spectra were collected in triplicate for each sample and then averaged.

In order to determine the main structural changes in the spectra that had undergone different treatments, a curve fitting using the Grams/386 spectroscopic software (version 6.00, Galactic Industries Corporation, Salem, NH, USA) was performed. The second derivative of the IR spectra in the 1800-1200 $\mathrm{cm}^{-1}$ region was smoothed using the Savitzky-Golay function. The IR spectra were fitted with Gaussian bands, and the best-fitting parameters were determined by minimization of the reduced chi-square $\left(\chi^{2}\right)$. Agreement between the experimental and calculated profiles was obtained, with coefficients of determination, $\mathrm{R}^{2}$, ranging from 0.990 to 0.980 and the standard error, SE, from 0.001 to 0.005 .

\subsection{Statistical Analyses}

Statistical analyses were assessed by using the XLSTAT software version 7.5.2 (Addinsoft, New York, NY, USA). Student $t$-test was performed to compare the $C$ and $N$ contents of the substrates after the mushrooms' mycelial growth with the initial substrates. The analysis of variance (ANOVA) was used to determinate a significant difference in the mycelial growth rate, fruiting body production and biological efficiency among different substrates. Tukey post hoc test $(p \leq 0.05)$ was used to compare the means.

Supplementary Materials: Figure S1: Growth of (1) C. aegerita, (2) C. comatus, (3) G. lucidum, (4) G. resinaceum, (5) L. sulphureus, (6) L. edodes, (7) M. importuna, (8) P. cornucopiae, (9) P. ostreatus and (10) S. commune in Petri dishes on (a) wheat straw (WS, red line), (b) corn digestate 50\%-wheat straw 50\% (CD-WS, blue line) and (c) corn digestate (CD, green line). Figure S2: Fruiting body production of $(\mathbf{a}, \mathbf{b})$ P. ostreatus and (c,d) P. cornucopiae. Table S1: Radial growth rate (mm/day) of the tested mushroom species on different substrates. Table S2: C/N ratio on different substrates before and after inoculation with the mushrooms.

Author Contributions: Conceptualization, O.F.; methodology P.L. and M.D.F.; validation, P.L.; formal analysis, P.L.; investigation, S.F., M.D.F. and F.P.; resources, A.Z. and O.F.; data curation P.L.; writing一original draft preparation, F.P.; writing-review and editing, A.Z. and O.F.; visualization, F.P. and supervision, O.F. and A.Z. All authors have read and agreed to the published version of the manuscript.

Funding: This research received no external funding. 
Acknowledgments: We would like to thank Biotec sys srl (Bologna, Italy) for providing us with the corn digestate and Renzo Gobbo of Azienda Agraria AUB, Cadriano, Granarolo dell'Emilia (BO) for the raw materials for the fungal cultivation.

Conflicts of Interest: The authors declare no conflicts of interest.

\section{References}

1. Appels, L.; Lauwers, J.; Degrve, J.; Helsen, L.; Lievens, B.; Willems, K.; Van Impe, J.; Dewil, R. Anaerobic digestion in global bio-energy production: Potential and research challenges. Renew. Sustain. Energy Rev. 2011, 15, 4295-4301. [CrossRef]

2. Being Wise with Waste: The EU's Approach to Waste Management. Available online: https:/ec.europa.eu/ environment/waste/pdf/WASTEBROCHURE.pdf (accessed on 23 March 2020).

3. Dahlin, J.; Nelles, M.; Herbes, C. Biogas digestate management: Evaluating the attitudes and perceptions of German gardeners towards digestate-based soil amendments. Resour. Conserv. Recycl. 2017, 118, $27-38$. [CrossRef]

4. Ahmed, B.; Aboudi, K.; Tyagi, V.K.; Álvarez-Gallego, C.J.; Fernández-Güelfo, L.A.; Romero-García, L.I.; Kazmi, A.A. Improvement of anaerobic digestion of lignocellulosic biomass by hydrothermal pretreatment. Appl. Sci. 2019, 9, 3853. [CrossRef]

5. Dashtban, M.; Schraft, H.; Qin, W. Fungal bioconversion of lignocellulosic residues: Opportunities \& perspectives. Int. J. Biol. Sci. 2009, 5, 578-595.

6. Plácido, J.; Capareda, S. Ligninolytic enzymes: A biotechnological alternative for bioethanol production. Bioresour. Bioprocess. 2015, 2, 23. [CrossRef]

7. Grigatti, M.; Montecchio, D.; Francioso, O.; Ciavatta, C. Structural and thermal investigation of three agricultural biomasses following mild- $\mathrm{NaOH}$ pretreatment to increase anaerobic biodegradability. Waste Biomass Valorization 2015, 6, 1135-1148. [CrossRef]

8. Mucha, A.P.; Dragisa, S.; Dror, I.; Garuti, M.; van Hullebusch, E.D.; Repinc, S.K.; Muňoz, J.; Rodriguez-Perez, S.; Stres, B.; Ustak, S. Re-use of digestate and recovery techniques. In Trace Elements in Anaerobic Biotechnologies; Fermoso, F.G., Van Hullebusch, E., Collins, G., Roussel, J., Mucha, A.P., Esposito, G., Eds.; IWA Publishing: London, UK, 2019; pp. 181-213.

9. Czubaszek, R.; Wysocka-Czubaszek, A. Emissions of carbon dioxide and methane from fields fertilized with digestate from an agricultural biogas plant. Int. Agrophysics 2018, 32, 29-37. [CrossRef]

10. Paolini, V.; Petracchini, F.; Segreto, M.; Tomassetti, L.; Naja, N.; Cecinato, A. Environmental impact of biogas: A short review of current knowledge. J. Environ. Sci. Heal.—Part A Toxic/Hazard. Subst. Environ. Eng. 2018, 53, 899-906. [CrossRef]

11. Hidalgo, D.; Martín-Marroquín, J.M.; Corona, F. A multi-waste management concept as a basis towards a circular economy model. Renew. Sustain. Energy Rev. 2019, 111, 481-489. [CrossRef]

12. Peng, W.; Lü, F.; Hao, L.; Zhang, H.; Shao, L.; He, P. Digestate management for high-solid anaerobic digestion of organic wastes: A review. Bioresour. Technol. 2020, 297, 122485. [CrossRef]

13. Janusz, G.; Pawlik, A.; Sulej, J.; Świderska-Burek, U.; Jarosz-Wilkolazka, A.; Paszczyński, A. Lignin degradation: Microorganisms, enzymes involved, genomes analysis and evolution. Fems Microbiol. Rev. 2017, 41, 941-962. [CrossRef] [PubMed]

14. Gupta, D.K.; Rühl, M.; Mishra, B.; Kleofas, V.; Hofrichter, M.; Herzog, R.; Pecyna, M.J.; Sharma, R.; Kellner, H.; Hennicke, F.; et al. The genome sequence of the commercially cultivated mushroom Agrocybe aegerita reveals a conserved repertoire of fruiting-related genes and a versatile suite of biopolymer-degrading enzymes. Bmc Genom. 2018, 19, 1-13. [CrossRef] [PubMed]

15. Sista Kameshwar, A.K.; Qin, W. Comparative study of genome-wide plant biomass-degrading CAZymes in white rot, brown rot and soft rot fungi. Mycology 2018, 9, 93-105. [CrossRef] [PubMed]

16. $\mathrm{Lu}, \mathrm{X}$.; Ding, S. Effect of $\mathrm{Cu}^{2+}, \mathrm{Mn}^{2+}$ and aromatic compounds on the production of laccase isoforms by Coprinus comatus. Mycoscience 2010, 51, 68-74. [CrossRef]

17. Tan, H.; Kohler, A.; Miao, R.; Liu, T.; Zhang, Q.; Zhang, B.; Jiang, L.; Wang, Y.; Xie, L.; Tang, J.; et al. Multi-omic analyses of exogenous nutrient bag decomposition by the black morel Morchella importuna reveal sustained carbon acquisition and transferring. Environ. Microbiol. 2019, 21, 3909-3926. [CrossRef] 
18. Dasanayaka, P.N.; Wijeyaratne, S.C. Cultivation of Schizophyllum commune mushroom on different wood substrates. J. Trop. For. Environ. 2017, 7, 65-73. [CrossRef]

19. Pleszczyńska, M.; Wiater, A.; Siwulski, M.; Szczodrak, J. Successful large-scale production of fruiting bodies of Laetiporus sulphureus (Bull.: Fr.) Murrill on an artificial substrate. World J. Microbiol. Biotechnol. 2013, 29, 753-758.

20. Oei, P. Mushroom Cultivation: Appropriate Technology for Mushroom Growers, 3rd ed.; Backhuys Publishers: Leiden, The Netherlands, 2003; p. 429.

21. Culture Medium for Cultivating Coprinus Comatus by Straw Raw Material Biogas Residues and Preparation Method Thereof. Available online: https://patents.google.com/patent/CN101113117A/en (accessed on 23 March 2020).

22. Liu, Q.; Ma, H.; Zhang, Y.; Dong, C. Artificial cultivation of true morels: Current state, issues and perspectives. Crit. Rev. Biotechnol. 2018, 38, 259-271. [CrossRef]

23. Lu, Y.; Lu, Y.C.; Hu, H.Q.; Xie, F.J.; Wei, X.Y.; Fan, X. Structural characterization of lignin and its degradation products with spectroscopic methods. J. Spectrosc. 2017, 2017. [CrossRef]

24. Tribot, A.; Amer, G.; Abdou Alio, M.; de Baynast, H.; Delattre, C.; Pons, A.; Mathias, J.D.; Callois, J.M.; Vial, C.; Michaud, P.; et al. Wood-lignin: Supply, extraction processes and use as bio-based material. Eur. Polym. J. 2019, 112, 228-240. [CrossRef]

25. Pandey, K.K.; Pitman, A.J. FTIR studies of the changes in wood chemistry following decay by brown-rot and white-rot fungi. Int. Biodeterior. Biodegrad. 2003, 52, 151-160. [CrossRef]

26. Gupta, B.S.; Jelle, B.P.; Gao, T. Application of ATR-FTIR spectroscopy to compare the cell materials of wood decay fungi with wood mould fungi. Int. J. Spectrosc. 2015, 2015, 1-7. [CrossRef]

27. Griffiths, P.R.; De Haseth, J.A. Fourier Transform Infrared Spectrometry, 2nd ed.; John Wiley \& Sons: New York, NY, USA, 2007; p. 509.

28. Rahman, M.R.; Hamdan, S.; Lai, J.C.H.; Jawaid, M.; bin Md Yusof, F.A. Physico-mechanical, thermal and morphological properties of furfuryl alcohol/2-ethylhexyl methacrylate/halloysite nanoclay wood polymer nanocomposites (WPNCs). Heliyon 2017, 3, e00342. [CrossRef] [PubMed]

29. Mohebby, B. Attenuated total reflection infrared spectroscopy of white-rot decayed beech wood. Int. Biodeterior. Biodegrad. 2005, 55, 247-251. [CrossRef]

30. Popescu, C.M.; Popescu, M.C.; Vasile, C. Structural changes in biodegraded lime wood. Carbohydr. Polym. 2010, 79, 362-372. [CrossRef]

31. Singh, S.; Harms, H.; Schlosser, D. Screening of ecologically diverse fungi for their potential to pretreat lignocellulosic bioenergy feedstock. Appl. Microbiol. Biotechnol. 2014, 98, 3355-3370. [CrossRef]

32. Huang, X.; Kocaefe, D.; Kocaefe, Y.; Boluk, Y.; Pichette, A. Study of the degradation behavior of heat-treated jack pine (Pinus banksiana) under artificial sunlight irradiation. Polym. Degrad. Stab. 2012, 97, 1197-1214. [CrossRef]

33. Colom, X.; Carrillo, F.; Nogués, F.; Garriga, P. Structural analysis of photodegraded wood by means of FTIR spectroscopy. Polym. Degrad. Stab. 2003, 80, 543-549. [CrossRef]

34. Yilgor, N.; Dogu, D.; Moore, R.; Terzi, E.; Kartal, S.N. Evaluation of fungal deterioration in Liquidambar orientalis Mill. Heartwood by FT-IR and light microscopy. BioResources 2013, 8, 2805-2826. [CrossRef]

35. Masaphy, S. Biotechnology of morel mushrooms: Successful fruiting body formation and development in a soilless system. Biotechnol. Lett. 2010, 32, 1523-1527. [CrossRef]

36. Möller, K.; Müller, T. Effects of anaerobic digestion on digestate nutrient availability and crop growth: A review. Eng. Life Sci. 2012, 12, 242-257. [CrossRef]

37. Monlau, F.; Sambusiti, C.; Ficara, E.; Aboulkas, A.; Barakat, A.; Carrère, H. New opportunities for agricultural digestate valorization: Current situation and perspectives. Energy Environ. Sci. 2015, 8, 2600-2621. [CrossRef]

38. Gioelli, F.; Dinuccio, E.; Balsari, P. Residual biogas potential from the storage tanks of non-separated digestate and digested liquid fraction. Bioresour. Technol. 2011, 102, 10248-10251. [CrossRef] [PubMed]

39. Menardo, S.; Gioelli, F.; Balsari, P. The methane yield of digestate: Effect of organic loading rate, hydraulic retention time, and plant feeding. Bioresour. Technol. 2011, 102, 2348-2351. [CrossRef]

40. Kuo, M.; Dewsbury, D.R.; O’Donnell, K.; Carter, M.C.; Rehner, S.A.; Moore, J.D.; Moncalvo, J.M.; Canfield, S.A.; Stephenson, S.L.; Methven, A.S.; et al. Taxonomic revision of true morels (Morchella) in Canada and the United States. Mycologia 2012, 104, 1159-1177. [CrossRef] [PubMed] 
41. Fanadzo, M.; Zireva, D.T.; Dube, E.; Mashingaidze, A.B. Evaluation of various substrates and supplements for biological efficiency of Pleurotus sajor-caju and Pleurotus ostreatus. Afr. J. Biotechnol. 2010, 9, 2756-2761.

42. Royse, D.J.; Rhodes, T.W.; Ohga, S.; Sanchez, J.E. Yield, mushroom size and time to production of Pleurotus cornucopiae (oyster mushroom) grown on switch grass substrate spawned and supplemented at various rates. Bioresour. Technol. 2004, 91, 85-91. [CrossRef]

43. Santi, G.; Muzzini, V.G.; Galli, E.; Proietti, S.; Moscatello, S.; Battistelli, A. Mycelial growth and enzymatic activities of white-rot fungi on anaerobic digestates from industrial biogas plants. Environ. Eng. Manag. J. 2015, 14, 1713-1719. [CrossRef]

44. Rajarathnam, S.; Wankhede, D.B.; Patwardhan, M.V. Some chemical and biochemical changes in straw constituents during growth of Pleurotus flabellatus (Berk \& Br) Sacc. Eur. J. Appl. Microbiol. Biotechnol. 1979, 8, 125-134.

45. Alexander, M. Mineralization and immobilization of nitrogen. In Introduction to Soil Microbiology; Alexander, M., Ed.; Wiley: New York, NY, USA, 1977; pp. 225-250.

46. Guo, T.; Zhang, Q.; Ai, C.; Liang, G.; He, P.; Zhou, W. Nitrogen enrichment regulates straw decomposition and its associated microbial community in a double-rice cropping system. Sci. Rep. 2018, 8, 1-12. [CrossRef]

47. Isikhuemhen, O.S.; Mikiashvili, N.A.; Kelkar, V. Application of solid waste from anaerobic digestion of poultry litter in Agrocybe aegerita cultivation: Mushroom production, lignocellulolytic enzymes activity and substrate utilization. Biodegradation 2009, 20, 351-361. [CrossRef]

48. Brezáni, A.; Svobodová, K.; Jablonský, I.; Tlustoš, P. Cultivation of medicinal mushrooms on spruce sawdust fermented with a liquid digestate from biogas stations. Int. J. Med. Mushrooms 2019, 21, 215-223. [CrossRef] [PubMed]

49. Kataki, S.; Sarma, G.D.; Patowary, D.; Baruah, D.C. Prospects of utilization of liquid fraction of biogas digestate as substrate supplement for mushroom cultivation. In Advances in Waste Management; Springer: Singapore, 2019; pp. 445-465.

50. Zhou, J.L.; Song, S.; Huang, Z.X.; Yang, L.; Jiao, A.G.; Liu, Y.; Wang, S.X. Cultivation of Pleurotus ostreatus, a potential candidate for biogas residues degradation. BioResources 2019, 13, 5432-5449.

51. Udayasimha, L.; Vijayalakshmi, Y.C. Sustainable waste management by growing mushroom (Pleurotus florida) on anaerobically digested waste and agro residues. Int. J. Eng. Res. Technol. 2012, 1, 1-8.

52. Isikhuemhen, O.S.; Mikiashvilli, N.A. Lignocellulolytic enzyme activity, substrate utilization, and mushroom yield by Pleurotus ostreatus cultivated on substrate containing anaerobic digester solids. J. Ind. Microbiol. Biotechnol. 2009, 36, 1353-1362. [CrossRef] [PubMed]

53. Islam, W.; Riaz, A. Yield and biological efficiency of Pleurotus ostreatus (Jacq. Fr.) cultivated upon various weeds and agricultural wastes. Pak. J. Weed Sci. Res. 2017, 23, 271-279.

54. Vieira, F.R.; de Andrade, M.C.N. Optimization of substrate preparation for oyster mushroom (Pleurotus ostreatus) cultivation by studying different raw materials and substrate preparation conditions (composting: Phases I and II). World J. Microbiol. Biotechnol. 2016, 32, 190. [CrossRef] [PubMed]

55. Stamets, P. Growing Gourmet and Medicinal Mushrooms; Ten Speed Press: Berkeley, CA, USA, 2000; p. 509.

56. Dias, A.A.; Freitas, G.S.; Marques, G.S.M.; Sampaio, A.; Fraga, I.S.; Rodrigues, M.A.M.; Evtuguin, D.V.; Bezerra, R.M.F. Enzymatic saccharification of biologically pre-treated wheat straw with white-rot fungi. Bioresour. Technol. 2010, 101, 6045-6050. [CrossRef]

57. Martínez, Á.T.; Speranza, M.; Ruiz-Dueñas, F.J.; Ferreira, P.; Camarero, S.; Guillén, F.; Martínez, M.J.; Gutiérrez, A.; Del Río, J.C. Biodegradation of lignocellulosics: Microbial, chemical, and enzymatic aspects of the fungal attack of lignin. Int. Microbiol. 2005, 8, 195-204.

58. Boddy, L.; Frankland, J.; West, P. Van Ecology of Saprotrophic Basidiomycetes; Academic Press; Elsevier: Amsterdam, The Netherlands, 2008; p. 386.

59. Kubicek, C. Fungi and Lignocellulosic Biomass; John Wiley \& Sons: Hoboken, NJ, USA, 2012; p. 304.

60. Mohd Hanafi, F.H.; Rezania, S.; Mat Taib, S.; Md Din, M.F.; Yamauchi, M.; Sakamoto, M.; Hara, H.; Park, J.; Ebrahimi, S.S. Environmentally sustainable applications of agro-based spent mushroom substrate (SMS): An overview. J. Mater. Cycles Waste Manag. 2018, 20, 1383-1396. [CrossRef]

61. Rinker, D.L. Handling and using "spent" mushroom substrate around the world. In Mushroom Biology and Mushroom Products, Proceedings of the Fourth International Conference on Mushroom Biology and Mushroom Products; Sánchez, J.E., Huerta, G., Montiel, E., Eds.; Universidad Autonoma del Estado de Morelos: Cuernavaca, Morelos, Mexico, 2002; pp. 43-60. 
62. Chiu, S.W.; Law, S.C.; Ching, M.L.; Cheung, K.W.; Chen, M.J. Themes for mushroom exploitation in the 21st century: Sustainability, waste management, and conservation. J. Gen. Appl. Microbiol. 2000, 46, 269-282. [CrossRef] [PubMed]

63. Amirta, R.; Herawati, E.; Suwinarti, W.; Watanabe, T. Two-steps utilization of Shorea wood waste biomass for the production of oyster mushroom and biogas-A zero waste approach. Agric. Agric. Sci. Procedia 2016, 9, 202-208. [CrossRef]

64. Mustafa, A.M.; Poulsen, T.G.; Sheng, K. Fungal pretreatment of rice straw with Pleurotus ostreatus and Trichoderma reesei to enhance methane production under solid-state anaerobic digestion. Appl. Energy 2016, 180, 661-671. [CrossRef]

65. Tuyen, D.V.; Phuong, H.N.; Cone, J.W.; Baars, J.J.P.; Sonnenberg, A.S.M.; Hendriks, W.H. Effect of fungal treatments of fibrous agricultural by-products on chemical composition and in vitro rumen fermentation and methane production. Bioresour. Technol. 2013, 129, 256-263. [CrossRef]

66. Mehta, V.; Gupta, J.K.; Kaushal, S.C. Cultivation of Pleurotus florida mushroom on rice straw and biogas production from the spent straw. World J. Microbiol. Biotechnol. 1990, 6, 366-370. [CrossRef]

67. Brabcová, V.; Nováková, M.; Davidová, A.; Baldrian, P. Dead fungal mycelium in forest soil represents a decomposition hotspot and a habitat for a specific microbial community. New Phytol. 2016, 210, 1369-1381. [CrossRef]

68. Yusidah, I.; Istifadah, N. The abilities of spent mushroom substrate to suppress basal rot disease (Fusarium oxysporum f.sp cepae) in shallot. Int. J. Biosci. 2018, 13, 440-448.

69. Trinci, A.P.J. Influence of the width of the peripheral growth zone on the radial growth rate of fungal colonies on solid media. J. Gen. Microbiol. 1971, 67, 325-344. [CrossRef]

70. Chang, S.T.; Lau, O.W.; Cho, K.Y. The cultivation and nutritional value of Pleurotus sajor-caju. Eur. J. Appl. Microbiol. Biotechnol. 1981, 12, 58-62. [CrossRef]

Sample Availability: Samples are not available from the authors.

(C) 2020 by the authors. Licensee MDPI, Basel, Switzerland. This article is an open access article distributed under the terms and conditions of the Creative Commons Attribution (CC BY) license (http://creativecommons.org/licenses/by/4.0/). 